NBER WORKING PAPER SERIES

\title{
ESTIMATING THE PRODUCTIVITY OF COMMUNITY COLLEGES IN PAVING THE ROAD TO FOUR-YEAR SUCCESS
}

\author{
Scott E. Carrell \\ Michal Kurlaender \\ Working Paper 22904 \\ http://www.nber.org/papers/w22904 \\ NATIONAL BUREAU OF ECONOMIC RESEARCH \\ 1050 Massachusetts Avenue \\ Cambridge, MA 02138 \\ December 2016
}

We thank the California Community College Chancellor's Office, the California State University Chancellor's Office, and the California Department of Education for their assistance with data access. Opinions reflect those of the authors and do not necessarily reflect those of the state agencies providing data. We thank Michel Grosz and Lester Lusher for their research assistance. The views expressed herein are those of the authors and do not necessarily reflect the views of the National Bureau of Economic Research.

NBER working papers are circulated for discussion and comment purposes. They have not been peer-reviewed or been subject to the review by the NBER Board of Directors that accompanies official NBER publications.

(C) 2016 by Scott E. Carrell and Michal Kurlaender. All rights reserved. Short sections of text, not to exceed two paragraphs, may be quoted without explicit permission provided that full credit, including ( $)$ notice, is given to the source. 
Estimating the Productivity of Community Colleges in Paving the Road to Four-Year Success

Scott E. Carrell and Michal Kurlaender

NBER Working Paper No. 22904

December 2016

JEL No. I23

\title{
ABSTRACT
}

The distinct mission and open-access nature of community colleges and the diverse goals of the students they serve make it difficult to assess differences in quality across community college campuses. In this paper, we investigate institutional differences in both the extensive and intensive margin of the transfer function across California's 108 community college campuses. Importantly, due to the richness of our dataset, we are able to adjust our estimates for a host of observed student differences, including scores on 11th grade math and English standardized tests. Results show there is significant variation in community college quality for both the probability of transfer as well as outcomes measuring how well students perform after transferring. Additionally, we examine whether any observable characteristics of the community college are significantly correlated with transfer productivity.

\author{
Scott E. Carrell \\ Department of Economics \\ University of California, Davis \\ One Shields Avenue \\ Davis, CA 95616 \\ and NBER \\ secarrell@ucdavis.edu \\ Michal Kurlaender \\ University of California, Davis \\ One Shields Avenue \\ School of Education \\ Davis, CA 95616 \\ mkurlaender@ucdavis.edu
}


Community colleges are the primary point of access to higher education for many Americans. Over 40 percent of all undergraduates attend a community college (College Board, 2014). In recent years, the Obama Administration has focused heavily on community colleges as critical drivers in the effort to increase the supply of college graduates in the U.S. Moreover, the push for free community colleges proposed by the White House, modeled after programs such as the Tennessee Promise, ${ }^{1}$ has also captured the attention of policymakers and the public at large.

Despite a relatively rich literature on the community college pathway, the research base on the quality differences between these institutions has been decidedly thin. The distinct mission and open-access nature of community colleges and the diverse goals of the students they serve make it difficult to assess differences in quality across campuses. Many suggest it is too difficult to identify which outcomes should actually be measured (Bailey, Calcagno, Jenkins, Leinbach, and Kienzl 2006). Nevertheless, strengthening outcomes at community colleges has been a large part of the national conversation about higher education accountability. Given the importance of the transfer pathway, it is critical to better understand institutional determinants of transfer success. Although several papers have explored the potential quality differences across community colleges, to our knowledge, no paper has explored differences in institutional quality in the preparation for transfer, tracking students from the two-year to the fouryear sector.

In this paper, we investigate institutional differences in both the extensive and intensive margin of the transfer function across California's 108 community college campuses. Specifically, we start with the extensive margin as in Kurlaender, Carrell and

\footnotetext{
${ }^{1} \mathrm{http}: / /$ tennesseepromise.gov
} 
Jackson (2016) by examining whether some community college campuses are significantly better (or worse) at producing students who transfer from the community college to a four-year college. Next, we examine the intensive margin of the transfer function by asking whether some community college campuses are better (or worse) at preparing students once they transfer to a BA granting institution. Importantly, due to the richness of our dataset, we are able to adjust our estimates for a host of observed student differences and potential unobserved determinates that drive selection. Most notable is the fact that our student-level college outcomes are linked to California high school records, which include scores on 11th grade math and English standardized tests. We are also able to control for unobservable differences that drive selection by controlling for four-year college fixed effects.

Additionally, we examine whether the community colleges, which are relatively more (or less) productive on the extensive margin of the transfer function, are also those colleges who are more (or less) productive on the intensive margin. Finally, we examine whether any observable characteristics of the community college are significantly correlated with transfer productivity.

The rest of the paper is organized as follows: in Section I we provide a brief background, reviewing some of the prior work on the transfer function and on community college quality; in Section II we describe the setting, data and methodological approach we employ for this analysis, in Section III we describe the findings, in Section IV we discuss mechanisms, and in Section $\mathrm{V}$ we conclude, providing a discussion of our findings and offering policy implications. 


\section{BACKGROUND AND SETTING}

\section{Background}

The multiple missions and goals of community colleges have been well documented in the academic literature (Bailey, Jaggars and Jenkins, 2015; Rosenbaum 2001; Dougherty 1994; Grubb 1991, 1996; Brint and Karabel 1983). The majority of community college systems are balancing at least three goals: basic skills instruction, career-technical education programs, and baccalaureate transfer pathways. Rising tuition, admissions standards and capacity constraints have limited access at many four-year universities making community colleges the primary pathway to a baccalaureate degree for many students.

The transfer function is one of the most important and scrutinized indicators of community college success (Long and Kurlaender, 2008; Melguizo, Kienzl, and Alfonso, 2011). On the one hand, community colleges offer an open pathway to the BA for those for whom a four-year BA granting institution may be out of reach (for financial, academic, or other reasons). However, the greater flexibility in enrollment afforded by community colleges (e.g. late entry, part-time, combining employment with schooling) may be detrimental to a student's academic progress, and lower their chances of transferring to a four-year college (Grubb, 1991; Brint and Karabel, 1989; Dougherty, 1994).

Much has been written about who utilizes the transfer route from community colleges and about the individual determinants of transfer success. Several papers have concluded that those who transfer from a community college to a four-year college are of 
a higher social class, have higher academic preparation, are less likely to be minority, and less likely to be female compared to the typical community college student (Gross and Goldhaber 2009; Dougherty and Kienzl, 2006; Adelman, 2006; Lee and Frank, 1990; Dougherty, 1987, 1994; Whitaker and Pascarella 1994; Grubb 1991). In fact, early work on the community college transfer route found that the socioeconomic status of the transfer group closely resembled the average social class of the original four-year college group (Dougherty 1994). Students' intent to transfer (Horn, 2009; Bradburn and Hurst 2001), need for developmental courses (Bettinger and Long 2009) and course enrollment patterns while at community college (Doyle 2009; Roksa and Calcagno 2010) are also key predictors of community college transfer. Among those who do transfer to four-year institutions and complete their degrees, community college students attain similar if not the same educational and occupational rewards (Melguizo and Dowd, 2008; Kane and Rouse 1995; Whitaker and Pascarella, 1994).

Far less is known about institutional differences in transfer success, specifically quality differences in the preparation community colleges offer students that transfer to BA-granting institutions. In a prior paper, we investigated institutional quality differences among community colleges and find meaningful differences in student outcomes across California's community colleges. For example, after adjusting for differences in student inputs, our lower bound estimates show that going from the $10^{\text {th }}$ to $90^{\text {th }}$ percentile of campus quality is associated with a 3.32 (34.3 percent) increase in student transfer units earned, a 0.07 (9.6 percent) increase in the probability of persisting to year two at the community college, a 0.09 (40.7 percent) increase in the probability of transferring to a 
four-year college, and a 0.08 (27.1 percent) increase in the probability of completion of a two-year degree (Kurlaender, Carrell, and Jackson 2016).

Clotfelter and colleagues (2013) explored variation in success measures across North Carolina's 58 community colleges, and find that conditional on student differences, colleges were largely indistinguishable from one another in degree receipt or transfer coursework, save for the differences between the very top and very bottom performing colleges (Clotfelter, Ladd, Muschkin, and Vigdor 2013). Similarly, Cunha and Miller (2014) examine institutional differences in student outcomes across Texas's 30 traditional four-year public colleges. Their results show that controlling for student background characteristics (e.g., race, gender, free lunch, SAT score, etc.), the quality of high school attended, and application behavior significantly reduces the mean differences in average earned income, persistence and graduation across four-year college campuses.

Several other papers have also looked at the role of different institutional inputs as proxies for institutional quality. In particular, Stange (2012) exploits differences in instructional expenditures per student across community colleges and finds no impact on student attainment (degree receipt or transfer). Calcagno and colleagues (2008) identify several institutional characteristics that influence student outcomes: larger enrollment, more minority students, and more part-time faculty are associated with lower degree attainment and lower 4-year transfer rates (Calcagno, Bailey, Jenkins, Kienzl, and Leinbach, 2008). 


\section{RESEARCH DESIGN}

\section{Setting}

California is home to the largest public higher education system in the nation. The 1960 Master Plan articulated the distinct functions of each of the State's three public postsecondary segments. The University of California (UC) is designated to as the state's primary academic research institution and is reserved for the top one eighth of the State's graduating high school class. The California State University (CSU) is primarily to serve the top one-third of California's high school graduating class in undergraduate training, and graduate training through the master's degree, focusing primarily on professional training such as teacher education. Finally, the California Community Colleges are to provide sub-baccalaureate instruction for students through the first two years of undergraduate education (lower division), as well as provide vocational instruction, remedial instruction, English as a Second Language courses, adult noncredit instruction, community service courses, and workforce training services.

Although the vision of the Master Plan and its legacy have been heavily debated among scholars and policymakers, the result is that the state has invested heavily in its postsecondary schooling systems, and today, $84 \%$ of California postsecondary students attend a public two-year or four-year college. In addition to building coherence across the State's public higher education institutions, the Master Plan is also often applauded for strengthening the importance of universal access to postsecondary schooling through the community colleges. Two-thirds of all college students attend a community college in California; in 2015 the Community College system served over 2.1 million students 
across 113 colleges, representing 20 percent of the nation's community college students. Students enrolled at community colleges represent enormous diversity in their backgrounds and educational goals; however, the far majority of community college enrollees intend to transfer to a four-year BA granting institution.

A central component of California's Master Plan is the articulation of transfer pathways from the community colleges to the state's BA-granting institutions though specific general education coursework. This was recently strengthened through California's Senate Bill 1440 knows as the Student Transfer Achievement Reform Act, which further reinforced articulation between the California Community Colleges and the California State University. The legislation required the community colleges to collaborate with the CSU to develop specific Associate Degrees for Transfer based on specified general education and lower division coursework at the community colleges to translate to junior standing at the CSU upon transfer. The primary goal of the legislation was to reduce unnecessary course taking and shorten time to degree.

The architects of the Master Plan for Higher Education envisioned an efficient process for students who start their postsecondary schooling at a community college to obtain a baccalaureate degree. Researchers, higher education leaders, and state policymakers alike have discussed and debated the community college transfer function for over half a century. Much of these discussions have focused on the importance of the transfer pathway for ensuring access, given capacity constraints at four-year institutions (Hill, 2006). However, to date, we know very little about how institutions fare in meeting their transfer function role. 
The California Community College Chancellor's Office calculates transfer rates for first time freshmen enrolled at community colleges based on two criteria: (1) 12 units earned and (2) attempt of a transfer level math or English course. Based on this definition, the transfer rates within five years of entry at a California community college are about $41 \%$ systemwide and vary widely from college to college. ${ }^{2}$ Other estimates are much lower and suggest that only 26 percent (Sengupta and Jepsen, 2006), or even 18 percent (Shulock and Moore, 2007) succeed in transferring to a four-year university or earn an associate's degree within six years. Horn and Lew (2007) compare California community college transfer rates across different denominators that define transfer seeking, and find very similar rates. Transfer rates also vary considerably by race/ethnicity. The raw gap in transfer rates between Hispanics and whites is 11.8 percentage points and between African Americans and whites 7.7 percentage points (CCCCO, 2011). National statistics—albeit somewhat dated—on the racial/ethnic gaps in transfer rates among BA intending students that are enrolled in 12 or more credit hours is only five percentage points between whites and African Americans and non-existent between whites and Hispanics (Bradburn and Hurst, 2001).

The community college students in California that do successfully transfer to a four-year college, overwhelmingly (about 80 percent) enroll at one of the campuses of the California State University (CSU) system. The 23-campus CSU system is the largest public four-year higher education system in the country, educating about 1 in 10 California high school graduates, roughly 5.5 percent of the undergraduates enrolled in

\footnotetext{
2 Calculations based on Transfer Rate Study of California Community College (2005-06 Report),
} Available at: http://www.cccco.edu/Portals/4/TRIS/research/reports/transfer_report.pdf 
public four-year colleges in the entire nation. ${ }^{3}$ The CSU system enrolls the largest majority of California community college transfer students. Among those that transfer nearly 90 percent apply to only one CSU, and 80 percent enroll in the CSU that is closest to their community college (home).

California is an ideal state in which to investigate institutional differences at community colleges because of the large number of institutions present. Moreover, articulation between the public two-year and broad access four-year colleges offers a unique opportunity to explore the transfer route more directly. California's public twoyear and four-year colleges are situated in urban, suburban and rural areas of the state, and their students come from public high schools that are both among the best and the worst in the nation. Thus, the diversity of California's community college population reflects the student populations of other states in the U.S. and the mainstream public twoyear colleges that educate them. As such, we believe that other states can learn important lessons from California's public postsecondary institutions.

\section{Data}

To explore institutional differences between community colleges in their transfer role, as well as BA completion, we constructed two administrative datasets that linked cohorts of California high school juniors to both the California Community College and the California State University campus they attended. These data were provided by the

\footnotetext{
3 This calculation is based on a published CSU enrollment of 437,000 students (http://www.calstate.edu/pa/2013Facts/documents/facts2013.pdf) and enrollment of 7.9 million student in public four year colleges nationwide in 2007

(http://nces.ed.gov/pubs2013/2013008.pdf).
} 


\section{California Community College Chancellor's Office, the California State University \\ Chancellor's Office, and the California Department of Education.}

First, to examine the extensive margin of the transfer function (the probability of transferring to a four-year college), we linked all transcript and completion data for four first time freshmen fall-semester cohorts (2004-2008) age 17-19, enrolled at a California community college with the census of California $11^{\text {th }}$ grade students with standardized test score data. The match, performed on name and birth date, high school attended, and cohort, initially captured 69 percent of first-time freshmen age 17-19 enrolled at a California community college (consistent with similar studies conducted by the California Community College Chancellor's Office matched to K-12 data). ${ }^{4}$

We restrict the sample for our study to first time freshman at the community college, of traditional age. We built cohorts of students who started in the summer or fall within one year of graduating high school, who attempted more than two courses (six units) in their first year, and had complete high school test and demographic information. This sample contains 389,187 students across 108 California community college campuses. $^{5}$

Second, to examine the intensive margin of the transfer function (how well students perform after transferring to a four-year college), we linked transcript level records of four cohorts (2005-2008) of California State University students who had

\footnotetext{
${ }^{4}$ Our match rates may be the result of several considerations. First, the name match occurred on the first three letters of a student's first name and last name, leading to many duplicates. Students may have entered different name or birthday at the community college. Students may have omitted information at either system. Second, the denominator may also be too high; not all community college students attended California high schools. Finally, students who did attend a California high school, but did not take the $11^{\text {th }}$ grade standardized tests were not included in the high school data.

${ }^{5}$ We excluded the three campuses that use the quarter system, as well as three adult education campuses. Summer students were only allowed in the sample if they took enough units in their first year to guarantee they also took units in the fall.
} 
transferred from a California Community College to their California High School records provided by the California Department of Education. Similar to the Community College data match, we linked the data on name, birth date, and gender. Using these identifiers we were able to successfully match $70 \%$ of all CSU transfers. Importantly, these data from the CSU system record whether the student transferred from a California Community College (CCC) and from which campus specifically. Additionally, these data include information on academic performance (GPA), persistence at the CSU, graduation, and time to degree.

\section{$\underline{\text { Measures }}$}

To examine institutional differences across community colleges in transfer and BA completion, we use multiple outcome measures. First, we with start with the extensive margin by examining the probability that a student transfers from a California Community College to any four-year college. Using National Student Clearinghouse data provided by the CCC Chancellor's office and linked to their own data records, we are able to tell whether a student transferred to a four-year college at any point after attending a California community college. As shown in Table 1, 27 percent of first time freshman at a CCC eventually transfer to a four-year school. We then split this outcome by whether the student transferred to a CSU campus or a University of California campus.

To examine the intensive margin of the transfer function, we next focus on what happens to students once they transfer to the CSU. We focus on the CSU because 52 percent of students in our sample, who transfer to a BA granting institution, transfer to 
one of the twenty-three CSU campuses, while only 15 percent transfer to one of the nine UC campuses. Specifically, we measure first-term GPA, persistence rates to year two, BA degree completion, and time to degree as measured by the probability of graduating within two or three years of transfer. Tables $1 \& 2$ show summary statistics for these key outcome measures at the individual and college level. The average transfer student earns a 2.78 GPA during their first term at the CSU (on a 0 to 4 point scale). A vast majority of transfer students persist to the second year at CSU, with persistence rates over 90 percent in our sample. Graduation rates among transfer students are relatively high at 71 percent. Finally, the average time to degree in our sample is just over three years while $34 \%$ and $71 \%$ of students graduate within two and three years of transfer, respectively.

Our data are unique in that we have the ability to connect a student's performance and outcomes at the community college and CSU with their high school data. As community colleges are open access, students do not submit transcripts from their high school, and have not necessarily taken college entrance exams such as the SAT or ACT to enter. As a result, community colleges often know very little about their students' prior educational backgrounds. Researchers interested in understanding the community college population often face the same constraints. Examining the outcomes of community colleges without considering the educational backgrounds of the students enrolling in that college may confound college effects with students' self-selection. Likewise, students who transfer to the CSU are also not required to take the ACT or SAT. To address these selection issues, we are able to adjust our estimates of quality by including, first, important background information about a student's high school academic performance. We measure a student's performance on the $11^{\text {th }}$ grade English 
and mathematics California Standardized Tests (CSTs). ${ }^{6}$ We are also able to determine which math course a student took in $11^{\text {th }}$ grade. In addition, we measure race/ethnicity, gender, and parental income. ${ }^{7}$ To account for high school quality, we include the Academic Performance Index (API) of the high school attended (California's school accountability metric). Importantly, as students are enrolling in community college, they are asked about their goals for attending community college. Students can pick from an extensive list of 15 choices, including: transfer with an associate's degree, transfer without an associate's degree, vocation certification, discover interests, improve basic skills, undecided, and others. We include students' self reported goals as an additional covariate for their postsecondary degree intentions. Lastly, we add additional controls for college-level means of our individual characteristics (eleventh grade CST math and English scores, race/ethnicity, gender, parental income, API, and student goal). Table 1 includes descriptive statistics on all of our measures at the individual level and Table 2 includes descriptive statistics at the college level. ${ }^{8}$

\section{Empirical Methods}

We begin by visually examining the raw outcome measures across the community colleges in our sample. Figure 1 presents the distribution of Proportion Transfer from

\footnotetext{
${ }^{6}$ We include CST scaled scores, which are approximately normally distributed across the state.

7 Our community college dataset contains information regarding whether the student was eligible for free and reduced priced lunch. Our CSU data file contains self-reported parental income measures. ${ }^{8}$ Unlike the four-year college quality literature, we do not account for students' college choice set since most community college students enroll in the school closest to where they attended high school. Using nationally representative data, Stange (2012) finds that in contrast to four-year college students, community college students do not appear to travel farther in search of higher quality campuses, and, importantly, "conditional on attending a school other than the closest one, there does not appear to be a relationship between student characteristics, school characteristics, and distance traveled among community college students," (Stange 2012: p. 81).
} 
CC, first-term GPA at CSU, Proportion Persisting to Year 2 at the CSU, Proportions Completing a BA, and Time to Degree across the 108 community colleges. This figure shows considerable variation across community college campuses in four of the five outcomes. The one exception is persistence to year 2 at the CSU, where a vast majority (95\%) of students persist to year two. To further examine the amount of variation in the four post-transfer CSU outcomes (first term GPA, persistence, graduation, and time to degree), in Figures 2 we plot the variation in these outcomes by community college campus and CSU campus. Each CSU (receiving institution) is plotted along the $\mathrm{X}$-axis with the corresponding sending community colleges plotted by size. These figures show two important facts. First, within each of the $23 \mathrm{CSU}$ campuses, students transfer from many different community colleges. Specifically, the average CSU campus in our sample period received transfer students from 79 different CCCs. Second, there is considerable variation in the average outcomes across these community colleges from which the students transfer within each CSU campus.

Although there appears to be considerable variation in average outcomes within CSUs and across CCC's, we note that our figures are unadjusted by student inputs. Therefore, to motivate the importance of accounting for student inputs, we next plot each outcome against students' eleventh grade math test scores at the college level (Figures 3). From these simple scatterplots it is clear that higher average student test scores are associated with better average CSU outcomes among transfer students, save for persistence. We also note that there is considerable variation in the average outcomes for students with similar high school test scores across the community colleges. 
To examine whether there are significant causal differences in the extensive transfer margin (i.e., the probability of transfer) across community college campuses, we start by estimating the following linear random effects model as in Kurlaender, Carrell, and Jackson (2016):

$$
Y_{i s c t y}=\beta_{0}+\beta_{1} x_{i}+\beta_{2} \bar{x}_{c y}+\beta_{3} w_{s}+\lambda_{t}+\phi_{y}+\zeta_{c}+\varepsilon_{i s c t y}
$$

where $Y_{i s c t y}$ is our outcome variables of interest (transfer to any four-year institutions, transfer to a CSU, or transfer to a UC) for individual $i$, from high school $s$, who is a firsttime freshman enrolled at community college $c$, in term $t$ in year $y ; x_{i}$ is a vector of individual-level characteristics (race/ethnicity, gender, parental education, and eleventh grade math and English language arts test scores), $\bar{x}_{c y}$ are community college by cohort means of $x_{i}$, and $w_{s}$ is a measure of the quality of the high school attended (California's API score $)^{9}$ for each individual; and $\varepsilon_{\text {iscty }}$ is the individual-level error term.

The main parameter of interest is the community college random effect, $\zeta_{c}{ }^{10} \mathrm{We}$ estimate $\widehat{\zeta}_{c}$ using an empirical Bayes shrinkage estimator to adjust for reliability. The empirical Bayes estimates are best linear unbiased predictors (BLUPs) of each community college's value added, which takes into account the variance (signal to noise) and the number of observations (students) at each college campus. Estimates of $\zeta_{c}$ with a higher variance and a fewer number of observations are shrunk towards zero (RabeHesketh and Skrondal 2008).

\footnotetext{
${ }^{9}$ The Academic Performance Index (API) is a measure of California schools' academic performance and growth. It is the chief component of California's Public Schools Accountability Act, passed in 1999. API is composed of schools' state standardized test scores and results on the California High School Exit Exam; scores range from a low of 200 to a high of 1000 .

${ }^{10}$ We use a random effects model instead of fixed effects model due to the efficiency (minimum variance) of the random effects model. However, our findings are qualitatively similar when using a fixed effects framework.
} 
The empirical Bayes technique is commonly used in measuring the quality of hospitals (Dimick, Staiger and Birkmeyer 2010), schools or neighborhoods (Altonji and Mansfield 2014), and teachers (Kane, Rockoff, and Staiger 2008; Carrell and West 2010). In particular, we use methodologies similar to those recently used in the literature to rank hospital quality, which shows the importance of adjusting mortality rates for patient risk (Parker et al. 2006) and statistical reliability (caseload size) (Dimick, Staiger, and Burkmeir 2019). In our context, we similarly adjust our college rankings for "student risk" (student preparation, high school quality, and unobserved determinants of selection) as well as potential noise in our estimates driven by differences in campus size and student population.

Next, to examine whether there are significant differences in the intensive transfer margin (i.e., how well students perform after transfer) across the cross community college campuses, we estimate the slightly modified linear random effects model to account for selection into the CSU:

$$
Y_{i s c t y u}=\beta_{0}+\beta_{1} x_{i}+\beta_{2} \bar{x}_{c y}+\beta_{3} w_{s}+\lambda_{t}+\phi_{y}+\zeta_{c}+\sigma_{u}+\varepsilon_{i s c t y u}
$$

where $Y_{i s c t y u}$ are the post-transfer outcome variables of interest (first term GPA, persistence, graduation, and time to degree) for individual $i$, from high school $s$, who is a first-time freshman enrolled at community college $c$, in term $t$ in year $y$ at CSU campus $u$. All other variables in the model are the same as in equation (2) and $\sigma_{u}$ are CSU campus fixed effects. Importantly, the CSU fixed effects controls for all unobserved (fixed) variation at the CSU campus level, for example, professor experience and teaching quality, level of support services, and other unobservable differences across the CSU campuses that influence post-transfer outcomes. Importantly, the CSU fixed effects also 
control for individual unobservable differences that drive selection into college selection and choice.

\section{RESUltS}

Extensive Margin Transfer Outcomes

We start by examining whether there are significant differences across community colleges in the probability of transferring to a four-year college as in Kurlaender, Carrell, and Jackson (2016). To do so, we examine whether there is significant variation in our estimates of $\widehat{\zeta}_{c}$ 's for our three transfer outcomes of interest. Table 3 presents results of the estimated standard deviation, $\sigma_{\widehat{\zeta}}$, in our college effects for various specifications of equation (1). High values of $\sigma_{\tilde{\zeta}}$ indicate there is significant variation in the probability of transferring across community college campuses, while low values of $\sigma_{\hat{\zeta}}$ would indicate that there is little difference in student transfer outcomes across campuses. In Specification 1, we start with the most naïve estimates where we include only year and term indicator variables. Results show that a one-standard deviation change in campus quality associated with a 0.072 percentage point increase in the probability transfer. This effect is quite large, representing a $27 \%$ increase from the mean in the probability of transfer. However, these unadjusted estimates are analogous to comparing simple means in student transfer rates across college campuses and likely overstate the true value-added of college campuses.

To adjust our estimates for differences in student-level inputs in Specifications 2 4 of Table 3 we sequentially adjust our estimates of $\widehat{\zeta}_{c}$ for a host of student-level covariates. This procedure is similar to the hospital quality literature that calculates risk 
adjusted mortality rates (Dimick, Staiger and Birkmeyer 2010). Importantly, starting in Specification 2, we include scores from the 11th grade California State Test (CST). Doing so likely removes a significant amount of potential bias in our estimates as the teacher quality literature has previously shown that teacher value-added estimates are unbiased when conditioning on prior year test scores (Kane \& Staiger, 2008). In Specification 3 we add individual-level demographic characteristics (race/ethnicity, gender, and parental income level). In Specification 4 we control for the student's goal for attending community college. In Specification 5 we add California's API scores for each student's high school to control for differences in high school quality.

Results in Specifications 2-5 indicate that even after controlling for student level observable characteristics there is considerable variation in transfer rates across California's community colleges. For Specification 5, a one-standard deviation increase in community college quality is associated with a 0.039 percentage point $(14.4 \%)$ increase in the probability of transferring to a four-year college.

In Specification 4 we add campus by cohort means of our various individual demographic variables to address concerns with selection on unobservables (Altonji, Elder, and Tabor 2005) as suggested Altonji and Masfield (2014), and to control for differences in peer quality, which has been shown to affect transfer outcomes (Smith and Stange, 2016). Doing so likely provides a lower bound of the estimated variance in the campus quality effects. ${ }^{11}$ In this fully specified model, our estimate remains unchanged

\footnotetext{
${ }^{11}$ Altonji and Mansfield (2014) show that, under reasonable assumptions, controlling for group means of individual-level characteristics "also controls for all of the across-group variation in the unobservable individual characteristics." This procedure provides a lower bound of the school quality effects because school quality is likely an unobservable that drives individual selection.
} 
with a one standard deviation increase in campus quality associated with a 0.039

percentage point (14.4-percent) increase in the probability of transferring.

In Columns 2 and 3 we present results when we split the outcome by whether the student transferred to a CSU campus or a University of California campus. Results show substantially higher variation across community college campuses in the probability of transferring to a CSU compared to a UC. Specifically, in our fully specified model, a one standard deviation in the community college effect is associated with a 2.7 percentage point increase in the probability of transferring to a CSU and a 1.8 percentage point increase in the probability of transferring to a UC.

\section{Intensive Margin Transfer Outcomes}

The previous results show significant variation across community college campuses in the probability of transferring to a BA granting institution. However, a natural follow-up question is whether some campuses produce students who perform better once they transfer? This question is analogous to the recent teacher quality literature that examines how teachers affect both contemporaneous academic achievement as well as longer term outcomes, such as later academic performance and labor market outcomes (Chetty, et. al, 2014; Carrell \& West, 2010). To answer this question, we next present results for our intensive margin outcomes that measure first-term GPA at the CSU, persistence to year 2 at the CSU, BA degree receipt, and time to degree as measured by the probability of graduating within two or three years at the CSU. As previously discussed, to overcome selection issues in college choice, we include CSU fixed effects in all our specifications, with results presented in Table 4. 
Analogous to our previously presented results, we start with a naive model that includes only year and term effects and well as CSU campus fixed effects. We then sequentially add control variables to the model. While the addition of control variables reduces the variation in the campus effects, significant variation in outcomes across community college campuses persist. Results for the fully specified model (Specification 5) show that a one standard deviation increase in community college campus quality is associated with a 0.066 (2.3 percent) increase in first-term GPA at the CSU, a 0.009 percentage point ( 1 percent) increase in the probability of persisting to year two, a 0.025 percentage point (3.6 percent) increase in the probability of BA completion, and a 0.028 percentage point ( 8.2 percent) increase in the probability of graduating within two years of transfer and a 2.3 percentage point ( 3.2 percent) increase in the probability of graduating within three years of transfer.

\section{MECHANISMS}

Understanding why some colleges are more successful than others in the transfer function (or in other outcomes) is of critical importance, and one that has captured the recent attention of higher education leaders in discussions about college quality prompted, in part, by the U.S. Department of Education's College Scorecard. ${ }^{12}$ Although there are many factors that may influence productivity, we explore this question by regressing the community college campus effects (BLUPs) that we estimate in Tables 3 and 4 on observable characteristics of the community college. Specifically, we explore whether the following attributes at the community college are correlated with the effectiveness of the college's transfer function outcomes: 1) tenured to adjunct faculty ratio, 2) female to

12 See: https://collegescorecard.ed.gov 
male faculty ratio, 3) faculty to student ratio, 4) support staff to student ratio, 5) faculty

experience, 6) distance to the nearest CSU, 7) school size, and 8) the fraction

degrees/certificates conferred that are vocational (career technical) education. ${ }^{13}$

Although we cannot claim the causality of the estimates, results show suggestive evidence that community colleges that are closer to a CSU, larger in size, have more female faculty, and have a lower fraction of students pursuing vocational education degrees are associated with better student transfer outcomes (Table 5).

For example, a one-mile increase in the distance to the CSU is correlated with a 0.02 percentage point decrease the probability of graduation $(\mathrm{p}=0.052)$. Likewise, $a$ 1,000 student ( 0.18 standard deviations) increase in the size of the community college is associated with significant increases in first term GPA (0.37 grade points), persistence to year two (0.03 percentage points), and graduating with a BA (0.08 percentage points).

As previously discussed, community colleges often have multiple missions. As such, it is not surprising that we find a negative correlation between our campus effect measuring the probability of transfer and the fraction of degrees and certificates conferred that are vocational. Specifically, we find that a one-percentage point increase in the fraction of vocationally oriented degrees/certificates awarded is associated with a nearly 9-percentage point decrease in the probability of transferring.

Finally, faculty characteristics appear to be potentially related to student outcomes. Although imprecisely estimated, results show that a 0.10 point increase in the female to male faculty ratio is associated with a 0.42 increase in GPA $(p=0.14)$ and a 0.016 percentage point increase in the probability of graduating within two years of

\footnotetext{
${ }^{13}$ We also examined financial indicators such as faculty salaries and institutional spending; however, these data were only available for a subset of our colleges (67 of 108). Within this subset of schools, we found no significant correlations between our estimated college effects and financial indicators.
} 
transfer $(\mathrm{p}=0.17)$. Several experimental and quasi-experimental studies have explored specific faculty characteristics and institutional practices and programs, and their impact on persistence and degree attainment. Studies exploring faculty characteristics have shown that professor gender, race/ethnicity, rank, education, and experience can significantly influence course performance, choice of major, and graduation (Carrell \& West, 2010; Carrell, Page, \& West, 2010; Fairlie, Hoffman, \& Oreopoulos, 2013; Hoffman \& Oreopoulos, 2009). However, it is unclear exactly why professor characteristics are correlated with student achievement.

A natural follow-up question is whether the community colleges that are relatively successful (or unsuccessful) in having their students transfer to a four-year college are the same community colleges that produce students who are relatively successful (or unsuccessful) at the four-year college after transferring? To explore this relationship, in Figure 5, we plot each community college's extensive margin effects against their intensive margin effects. ${ }^{14}$ The pattern of results suggests that there is a small positive relationship between the probability of transfer and student performance after transfer. That is, the community colleges that are more (or less) successful at producing students who transfer to a four-year college also produce students who tend to perform better (or worse) after transferring (in terms of GPA, graduation, and time to degree).

\section{CONClusion}

${ }^{14}$ We plot the Best Linear Unbiased Predictors (BLUPs) of each community college's random effects. 
To our knowledge, this is the first study in the literature to examine how institutional differences across community colleges affect both the extensive and intensive margin of the transfer function. Results show there is significant variation in community college quality for both the probability of transfer as well as outcomes measuring how well students perform after transferring.

Overall, our results show significant differences across community colleges in both the intensive and extensive margin of the transfer function. Specifically, after adjusting for observable student differences and unobservable factors that drive selection, we find that some community colleges are relatively more (or less) efficient in producing students who are more likely to transfer and to achieve at a higher level at their posttransfer institutions.

There is a small positive relationship between the extensive and intensive margin outcomes, indicating that the schools that are better at producing students who transfer also produces students who, on average, perform equally or better at their four-year institutions, post-transfer. We find some evidence that observable characteristics of the community colleges are correlated with transfer productivity. Specifically, larger community colleges, colleges closer to a CSU and colleges with more female faculty are associated with more positive transfer outcome. (In ongoing work we also examine productivity by student type: academic preparation, income and race.)

Of course there may be a host of factors we don't observe that make some of these institutions more effective at the transfer function than others. The transfer process is complex and navigating it successfully requires an understanding of the requirements to do so-at two different institutions (i.e. the sending community college and the 
receiving CSU). Thus, it is likely that colleges vary greatly in their ability to direct students along this pathway (for example, through improved information, counseling, course articulation, or even scheduling).

To date, much of the research on college quality has focused largely on more selective four-year colleges and universities. Yet, the increased policy focus on community colleges demands careful attention to quality differences among these openaccess institutions, particularly in facilitating transfer and degree completion. In this paper we leverage rich administrative data from two of the largest public higher education systems to investigate institutional quality differences across community colleges in their efforts to prepare and pave the road for transfer students in pursuit of the BA. 


\section{REFERENCES}

Adelman, C. (2006). The Toolbox Revisited. Washington, D.C.: U.S. Department of Education.

Altonji, Joseph G., Todd E. Elder, and Christopher R. Taber. 2005. "Selection on Observed and Unobserved Variables: Assessing the Effectiveness of Catholic Schools," Journal of Political Economy, University of Chicago Press, vol. 113(1), pages 151-184, February.

Altonji Joseph and Richard Mansfield. 2014. "Group-Average Observables as Controls for Sorting on Unobservables When Estimating Group Treatment Effects: the Case of School and Neighborhood Effects," Working Paper.

Bailey, Thomas, Juan Carlos Calcagno, Davis Jenkins, Timothy Leinbach, and Gregory Kienzl. 2006. "Is Student-Right-to-Know All You Should Know? An Analysis of Community College Graduation Rates." Research in Higher Education 47(5):491-519.

Bailey, Thomas, Shaunna Jaggars and Davis Jenkins. 2015. Redesigning America's community colleges. New York, NY: Teacher's College.

Bettinger, Eric and Bridget Terry Long, 2009. "Addressing the Needs of Underprepared Students in Higher Education: Does College Remediation Work?," Journal of Human Resources, University of Wisconsin Press, vol. 44(3).

Bradburn, E. M., \& Hurst, D. G. (2001). Community college transfer rates to 4-year institutions using alternative definitions of transfer. Washington, DC: U.S. Department of Education, National Center for Education Statistics.

Brand, Jennie E. and Charles N. 2006. "Regression and Matching Estimates of the Effects of Elite College Attendance on Educational and Career Achievement." Social Science Research 35:749-770.

Brint, Steve. \& Jerome Karabel. 1989. The Diverted Dream: Community Colleges and the Promise of Educational Opportunity in America, 1900-1985. New York: Oxford University Press.

Brint, S. \& Karabel, J. (1989). The Diverted Dream: Community Colleges and the Promise of Educational Opportunity in America, 1900-1985. New York: Oxford University Press.

Calcagno, Juan Carlos, Thomas Bailey, Davis Jenkins, Gregory Kienzl, and Timothy Leinbach. 2008. Community college student success: What institutional characteristics make a difference? Economics of Education Review, 27: 632-645. 
Carrell, Scott E. and James E. West. 2010. "Does Professor Quality Matter? Evidence from Random Assignment of Students to Professors," Journal of Political Economy, University of Chicago Press, vol. 118(3), pages 409-432, 06.

Chetty, Raj, Nathanial Hendren, Patrick Kline and Emmanuel Saez. 2014. Where is the land of opportunity? The geography of intergenerational mobilityin the United States. Quarterly Journal of Economics, 129(4) 1553-1623

Clotfelter, Charles T., Helen F. Ladd, Clara G. Muschkin, and Jacob L. Vigdor. 2013. "Success in Community College: Do Institutions Differ?," Research in Higher Education, 54:805-824.

Cunha, Jesse and Trey Miller. 2013. "Measuring Value-Added in Higher Education: Possibilities and Limitations in the Use of Administrative Data," Economics of Education Review, 42:64-77.

Dimick, Justin, Douglas Staiger, and John Birkmeyer. 2010. "Ranking Hospitals on Surgical Mortality: The Importance of Reliability Adjustment," Health Services Research, 45(6).

Dougherty, Kevin J. 1994. The Contradictory College: The Conflicting Origins, Impacts, and Futures of the Community College. Albany, NY: State University of New York Press.

Dougherty, K. J., \& Kienzl, G. S. (2006). It's not enough to get through the open door: Inequalities by social background in transfer from community colleges to four-year colleges. Teachers College Record, 108 (3), 452-487.

Dougherty, K. (1987). The Effects of Community Colleges: Aid or Hindrance to Socioeconomic Attainment? Sociology of Education, 60(2): 86-103.

Goldhaber, Dan, Stephanie Liddle, Roddy Theobald, and Joe Walch. 2010. “Teacher Effectiveness and the Achievement of Washington's Students in Mathematics," Center for Education Data \& Research, University of Washington, Working Paper 2010-06.

Gross, Betheny and Dan Goldhaber. 2009. Community college transfer and articulation: policies: Looking beneath the surface. Seattle WA: Center for Reinventing Public Education

Grubb, W. Norton. 1991. The Decline of Community College Transfer Rates: Evidence from National Longitudinal Surveys. Journal of Higher Education, 62(2): 194-222.

Horn, L. \& Lew, S. (2007). California Community College Transfer Rates Who Is Counted Makes a Difference. MPR Research Brief. Available at: http://mprinc.com/products/pdf/horn_ccc.pdf 
Kane, Thomas J., Jonah E. Rockoff, and Douglas O. Staiger. 2008. What Does

Certification Tell Us About Teacher Effectiveness? Evidence from New York City. Economics of Education Review 27 (6):615 631.

Kane, Thomas J., and Cecilia Elena Rouse. 1999. The Community College: Educating Students at the Margin between College and Work. Journal of Economic Perspectives, 13(1): $63-84$

Kurlaender, Michal, Scott Carrell and Jacob Jackson. 2016. The Promises and Pitfalls of Measuring Community College Quality, The Russell Sage Foundation Journal of the Social Sciences, 2(1), 174-190

Lee, V. and Frank, K. (1990). Students' Characteristics that facilitate the Transfer from Two-year to Four-year Colleges. Sociology of Education, 63(3): 178-193.

Long, B. T. and Kurlaender, M. (2009). Do Community Colleges Provide a Viable Pathway to Baccalaureate Degree? Educational Evaluation and Policy Analysis, 31 (1):30-53.

Melguizo, T., \& Dowd, A.C. (2008). Baccalaureate Success of Transfers and Rising Four-Year College Juniors. Teachers College Record, 111 (1):55-89

Tatiana Melguizo, T. , Kienzl, G. S., Alfonso, M. (2011). Comparing the Educational Attainment of Community College Transfer Students and Four-Year College Rising Juniors Using Propensity Score Matching Method, The Journal of Higher Education, 82 (3): 265-291.

Parker, J. P., Z. Li, C. L. Damberg, B. Danielsen, and D. M. Carlisle. 2006. “'Administrative versus Clinical Data for Coronary Artery Bypass Graft Surgery Report Cards: The View from California.' Medical Care, 44 (7): 687-95.

Rabe-Hesketh, Sophia and Anders Skrondal. 2008. Multilevel and Longitudinal Modeling Using Stata. College Station, TX: Stata Press, second ed.

Roksa, Josipa, and Juan Carlos Calcagno. 2010. "Catching Up in Community Colleges: Academic Preparation and Transfer to Four-Year Institutions." Teachers College Record 112:260-288.

Rosenbaum, James. 2001. Beyond college for all: career paths for the forgotten half. Russell Sage Foundation.

Sengupta, Ria, and Christopher Jepsen.2006. California's Community College Students. California Counts: Population Trends and Profiles, 8 (2). Public Policy Institute of California. 
Shulock, Nancy, and Colleen Moore. 2007. Rules of the Game: How State Policy Creates Barriers to Degree Completion and Impedes Student Success in the California Community Colleges. Sacramento, CA: Institute for Higher Education and Leadership.

Smith, Jonathan and Kevin, Stange, 2016. A New Measure of College Quality to Study the Effects of College Sector and Peers on Degree Attainment. Education Finance and Policy, forthcoming

Stange, Kevin. 2012. Ability Sorting and the Importance of College Quality to Student Achievement: Evidence from Community Colleges, Education Finance and Policy, 7 (1): 74-105.

Whitaker, D. \& Pascarella, E. (1994). Two-Year College Attendance and Socioeconomic Attainment: Some Additional Evidence. Journal of Higher Education, 65(2): 194-210. 
TABLES \& Figures

Table 1. Sample Descriptive Statistics by Student

\begin{tabular}{|c|c|c|c|c|c|}
\hline Variable & Mean & Std. Dev. & Min & Max & Observations \\
\hline \multicolumn{6}{|l|}{$\overline{\text { CC Outcomes }}$} \\
\hline Ever Transfer & 0.27 & 0.44 & 0 & 1 & 389,187 \\
\hline Transfer to CSU & 0.14 & 0.43 & 0 & 1 & 389,187 \\
\hline Transfer to UC & 0.04 & 0.34 & 0 & 1 & 389,187 \\
\hline \multicolumn{6}{|l|}{ CSU Outcomes } \\
\hline First Term GPA & 2.78 & 0.88 & 0 & 4 & 66,427 \\
\hline Persist to Year Two & 0.95 & 0.23 & 0 & 1 & 66,427 \\
\hline Graduate with BA & 0.71 & 0.46 & 0 & 1 & 66,427 \\
\hline Time to Degree (Years) & 3.14 & 1.21 & 1 & 9 & 46,378 \\
\hline TTD $<=2$ Years & 0.34 & 0.47 & 0 & 1 & 46,378 \\
\hline TTD $<=3$ Years & 0.71 & 0.45 & 0 & 1 & 46,378 \\
\hline Covariates & & & & & 389,187 \\
\hline English Test Score & 333.65 & 55.7 & 150 & 600 & 389,187 \\
\hline Math Test Score & 291.64 & 48.98 & 150 & 600 & 389,187 \\
\hline Asian & 0.08 & 0.27 & 0 & 1 & 389,187 \\
\hline Pacific Islander & 0.01 & 0.08 & 0 & 1 & 389,187 \\
\hline Filipino & 0.05 & 0.21 & 0 & 1 & 389,187 \\
\hline Hispanic & 0.39 & 0.49 & 0 & 1 & 389,187 \\
\hline Black & 0.07 & 0.25 & 0 & 1 & 389,187 \\
\hline White & 0.40 & 0.49 & 0 & 1 & 389,187 \\
\hline Did Not State Race & 0.01 & 0.08 & 0 & 1 & 389,187 \\
\hline Female & 0.50 & 0.50 & 0 & 1 & 389,187 \\
\hline Eligible for Subsidized Lunch & 0.32 & 0.47 & 0 & 1 & 389,187 \\
\hline Parent Income $<\$ 24 \mathrm{~K}$ & 0.11 & 0.32 & 0 & 1 & 66,427 \\
\hline Parent Income $\$ 24 \mathrm{~K}-\$ 36 \mathrm{~K}$ & 0.09 & 0.28 & 0 & 1 & 66,427 \\
\hline Parent Income $\$ 36 \mathrm{~K}-\$ 48 \mathrm{~K}$ & 0.07 & 0.25 & 0 & 1 & 66,427 \\
\hline Parent Income $\$ 48 \mathrm{~K}-\$ 60 \mathrm{~K}$ & 0.07 & 0.25 & 0 & 1 & 66,427 \\
\hline Parent Income $\$ 60 \mathrm{~K}-\$ 72 \mathrm{~K}$ & 0.07 & 0.25 & 0 & 1 & 66,427 \\
\hline Parent Income $>\$ 72 \mathrm{~K}$ & 0.27 & 0.44 & 0 & 1 & 66,427 \\
\hline Parent Income Missing & 0.33 & 0.47 & 0 & 1 & 66,427 \\
\hline High School API & 707.91 & 79.00 & 272.00 & 987.00 & 254,865 \\
\hline
\end{tabular}

Notes: Variables with 389,287 observations come from the Californial Community College datafile, while variables with 66,427 observations come from the CSU datafile. 
Table 2. Sample Descriptive Statistics by Community College

\begin{tabular}{|c|c|c|c|c|}
\hline \multirow{2}{*}{\multicolumn{5}{|c|}{$\begin{array}{l}\text { Variable } \\
\text { Outcomes }\end{array}$}} \\
\hline & & & & \\
\hline Ever Transfer & 0.25 & 0.08 & 0.06 & 0.43 \\
\hline Transfer to CSU & 0.12 & 0.05 & 0.01 & 0.22 \\
\hline Transfer to UC & 0.04 & 0.03 & 0.00 & 0.16 \\
\hline \multicolumn{5}{|l|}{ CSU Outcomes } \\
\hline First Term GPA & 2.74 & 0.17 & 2.22 & 3.12 \\
\hline Persist to Year Two & 0.93 & 0.04 & 0.67 & 1.00 \\
\hline Graduate with BA & 0.68 & 0.09 & 0.29 & 0.81 \\
\hline Time to Degree (TTD) & 3.20 & 0.24 & 2.67 & 4.05 \\
\hline TTD $<=2$ Years & 0.32 & 0.09 & 0.00 & 0.55 \\
\hline TTD $<=3$ Years & 0.69 & 0.09 & 0.25 & 0.86 \\
\hline \multicolumn{5}{|l|}{ Covariates } \\
\hline English Test Score (std) & -0.05 & 0.27 & -0.79 & 0.56 \\
\hline Math Test Score (std) & -0.04 & 0.25 & -0.72 & 0.44 \\
\hline Asian & 0.07 & 0.07 & 0 & 0.37 \\
\hline Pacific Islander & 0.01 & 0.01 & 0 & 0.05 \\
\hline Filipino & 0.04 & 0.05 & 0 & 0.27 \\
\hline Hispanic & 0.37 & 0.2 & 0.06 & 0.91 \\
\hline Black & 0.08 & 0.11 & 0.01 & 0.69 \\
\hline White & 0.41 & 0.22 & 0.01 & 0.85 \\
\hline Did Not State Race & 0.01 & 0.01 & 0 & 0.05 \\
\hline Female & 0.5 & 0.04 & 0.39 & 0.65 \\
\hline Eligible for Subsidized Lunch & 0.34 & 0.16 & 0.07 & 0.73 \\
\hline Parent Income $<\$ 24 \mathrm{~K}$ & 0.11 & 0.08 & 0 & 0.41 \\
\hline Parent Income $\$ 24 \mathrm{~K}-\$ 36 \mathrm{~K}$ & 0.09 & 0.04 & 0 & 0.17 \\
\hline Parent Income $\$ 36 \mathrm{~K}-\$ 48 \mathrm{~K}$ & 0.07 & 0.03 & 0 & 0.27 \\
\hline Parent Income $\$ 48 \mathrm{~K}-\$ 60 \mathrm{~K}$ & 0.07 & 0.05 & 0 & 0.50 \\
\hline Parent Income $\$ 60 \mathrm{~K}-\$ 72 \mathrm{~K}$ & 0.07 & 0.02 & 0 & 0.13 \\
\hline Parent Income $>\$ 72 \mathrm{~K}$ & 0.27 & 0.10 & 0 & 0.46 \\
\hline Parent Income Missing & 0.33 & 0.08 & 0 & 0.66 \\
\hline High School API & 703.26 & 45.03 & 588.34 & 799.11 \\
\hline \multicolumn{5}{|l|}{ Community College Characteristics $(n=102)$} \\
\hline Tenured to Adjunct Faculty Ratio & 0.94 & 0.37 & 0.24 & 2.53 \\
\hline Female to Male Faculty Ratio & 0.96 & 0.20 & 0.55 & 2.00 \\
\hline Faculty to Student Ratio & 56.47 & 23.55 & 16.21 & 160.02 \\
\hline Support Staff to Student Ratio & 3.26 & 2.34 & 0.00 & 12.30 \\
\hline Faculty Years of Experience & 5.10 & 0.83 & 2.49 & 7.61 \\
\hline Distance to the nearest CSU (miles) & 19.42 & 25.12 & 0.89 & 159.52 \\
\hline Student Population $(1,000$ 's $)$ & 8.62 & 5.46 & 1.93 & 28.87 \\
\hline Fraction Vocational Education Degrees/Certificates & 51.33 & 13.81 & 6.35 & 82.51 \\
\hline
\end{tabular}


Table 3. Standard Deviations in Random Effects: Community College Outcomes

\begin{tabular}{llccc}
\hline \multirow{2}{*}{ Specification } & \multirow{3}{c}{ Controls } & \multicolumn{3}{c}{ S.D. of Random Effects Estimates } \\
\cline { 3 - 5 }$(1)$ & \multirow{2}{*}{ Year/term } & 0.072 & Transfer to CSU & Transfer to UC \\
\cline { 3 - 5 }$(2)$ & & 0.040 & 0.029 \\
& Test scores & $0.054,0.082]$ & {$[0.035,0.046]$} & {$[0.025,0.033]$} \\
(3) & {$[0.047,0.062]$} & 0.034 & 0.023 \\
& Demographics & 0.047 & $0.030,0.040]$ & {$[0.020,0.026]$} \\
(4) & & {$[0.041,0.054]$} & {$[0.027,0.036]$} & {$[0.019,0.025]$} \\
& Goal & 0.044 & 0.029 & 0.021 \\
(5) & & {$[0.038,0.050]$} & {$[0.025,0.033]$} & {$[0.019,0.025]$} \\
& School API & 0.039 & 0.027 & 0.021 \\
(6) & & $0.034,0.045]$ & {$[0.023,0.031]$} & {$[0.018,0.024]$} \\
& College Means & 0.041 & 0.026 & 0.019 \\
\hline \# of Community Colleges & {$[0.035,0.047]$} & {$[0.022,0.031]$} & {$[0.016,0.022]$} \\
\hline
\end{tabular}

Notes: Each cell represents the standard deviation of the community college random effects. $95 \%$ confidence intervals in brackets. 
Table 4. Standard Deviations in Random Effects: CSU Outcomes

\begin{tabular}{|c|c|c|c|c|c|c|}
\hline \multirow[b]{2}{*}{ Specification } & \multirow[b]{2}{*}{ Controls } & \multicolumn{5}{|c|}{ S.D. of Random Effects Estimates } \\
\hline & & First Term GPA & $\begin{array}{l}\text { Persist to Year } \\
\text { Two }\end{array}$ & Graduate with BA & TTD $<=2$ Years & TTD $<=3$ Years \\
\hline (1) & Year/term & $\begin{array}{c}0.122 \\
{[0.103,0.145]}\end{array}$ & $\begin{array}{c}0.011 \\
{[0.008,0.015]}\end{array}$ & $\begin{array}{c}0.039 \\
{[0.031,0.048]}\end{array}$ & $\begin{array}{c}0.041 \\
{[0.033,0.050]}\end{array}$ & $\begin{array}{c}0.036 \\
{[0.028,0.044]}\end{array}$ \\
\hline (2) & Test scores & $\begin{array}{c}0.105 \\
{[0.088,0.126]}\end{array}$ & $\begin{array}{c}0.011 \\
{[0.008,0.014]}\end{array}$ & $\begin{array}{c}0.038 \\
{[0.030,0.047]}\end{array}$ & $\begin{array}{c}0.040 \\
{[0.032,0.050]}\end{array}$ & $\begin{array}{c}0.036 \\
{[0.028,0.045]}\end{array}$ \\
\hline (3) & Demographics & $\begin{array}{c}0.088 \\
{[0.072,0.106]}\end{array}$ & $\begin{array}{c}0.010 \\
{[0.007,0.014]}\end{array}$ & $\begin{array}{c}0.034 \\
{[0.027,0.042]}\end{array}$ & $\begin{array}{c}0.035 \\
{[0.027,0.044]}\end{array}$ & $\begin{array}{c}0.030 \\
{[0.023,0.038]}\end{array}$ \\
\hline (4) & School API & $\begin{array}{c}0.085 \\
{[0.070,0.104]}\end{array}$ & $\begin{array}{c}0.010 \\
{[0.007,0.014]}\end{array}$ & $\begin{array}{c}0.031 \\
{[0.024,0.040]}\end{array}$ & $\begin{array}{c}0.033 \\
{[0.026,0.043]}\end{array}$ & $\begin{array}{c}0.028 \\
{[0.021,0.036]}\end{array}$ \\
\hline (5) & College Means & $\begin{array}{c}0.066 \\
{[0.054,0.082]}\end{array}$ & $\begin{array}{c}0.009 \\
{[0.006,0.013]}\end{array}$ & $\begin{array}{c}0.025 \\
{[0.019,0.033]}\end{array}$ & $\begin{array}{c}0.028 \\
{[0.022,0.037]}\end{array}$ & $\begin{array}{c}0.023 \\
{[0.017,0.031]}\end{array}$ \\
\hline \# of Commur & ity Colleges & 108 & 108 & 108 & 108 & 108 \\
\hline
\end{tabular}

Notes: Each cell represents the standard deviation of the community college random effects. All specifications include CSU fixed effects. $95 \%$ confidence intervals in brackets. 
Table 5. College Random Effects Regressed on Observable Characteristics

\begin{tabular}{|c|c|c|c|c|c|c|c|}
\hline Specification & (1) & $(2)$ & (3) & (4) & $(5)$ & $(6)$ & $(6)$ \\
\hline Variable & Transfer Ever & $\begin{array}{c}\text { Transfer to } \\
\text { CSU }\end{array}$ & $\begin{array}{c}\text { First Term } \\
\text { GPA }\end{array}$ & $\begin{array}{l}\text { Persist to } \\
\text { Year Two }\end{array}$ & $\begin{array}{c}\text { Graduate } \\
\text { with BA }\end{array}$ & $\begin{array}{c}\text { TTD }<=2 \\
\text { Years }\end{array}$ & $\begin{array}{c}\text { TTD }<=3 \\
\text { Years }\end{array}$ \\
\hline Tenured to Adjunct Faculty Ratio & $\begin{array}{c}-0.707 \\
(1.066)\end{array}$ & $\begin{array}{c}0.749 \\
(0.721)\end{array}$ & $\begin{array}{c}2.237 \\
(1.494)\end{array}$ & $\begin{array}{c}0.068 \\
(0.147)\end{array}$ & $\begin{array}{c}0.359 \\
(0.524)\end{array}$ & $\begin{array}{c}0.359 \\
(0.602)\end{array}$ & $\begin{array}{c}0.640 \\
(0.452)\end{array}$ \\
\hline Female to Male Faculty Ratio & $\begin{array}{l}-0.553 \\
(2.049)\end{array}$ & $\begin{array}{c}0.106 \\
(1.386)\end{array}$ & $\begin{array}{c}3.806 \\
(2.872)\end{array}$ & $\begin{array}{c}0.373 \\
(0.283)\end{array}$ & $\begin{array}{c}0.618 \\
(1.006)\end{array}$ & $\begin{array}{c}1.563 \\
(1.157)\end{array}$ & $\begin{array}{c}0.935 \\
(0.869)\end{array}$ \\
\hline Faculty to Student Ratio & $\begin{array}{l}-0.024 \\
(0.019)\end{array}$ & $\begin{array}{l}-0.014 \\
(0.013)\end{array}$ & $\begin{array}{c}0.030 \\
(0.027)\end{array}$ & $\begin{array}{c}0.002 \\
(0.003)\end{array}$ & $\begin{array}{l}-0.005 \\
(0.009)\end{array}$ & $\begin{array}{c}0.006 \\
(0.011)\end{array}$ & $\begin{array}{l}-0.008 \\
(0.008)\end{array}$ \\
\hline Support Staff to Student Ratio & $\begin{array}{c}0.289 \\
(0.184)\end{array}$ & $\begin{array}{l}0.066 \\
(0.125)\end{array}$ & $\begin{array}{l}0.067 \\
(0.258)\end{array}$ & $\begin{array}{c}-0.014 \\
(0.025)\end{array}$ & $\begin{array}{l}-0.013 \\
(0.091)\end{array}$ & $\begin{array}{c}-0.109 \\
(0.104)\end{array}$ & $\begin{array}{l}0.063 \\
(0.078)\end{array}$ \\
\hline Average Faculty Years of Experience at the College & $\begin{array}{l}-0.354 \\
(0.519)\end{array}$ & $\begin{array}{c}-0.089 \\
(0.351)\end{array}$ & $\begin{array}{l}-0.637 \\
(0.727)\end{array}$ & $\begin{array}{l}0.066 \\
(0.072)\end{array}$ & $\begin{array}{c}-0.180 \\
(0.255)\end{array}$ & $\begin{array}{l}-0.145 \\
(0.293)\end{array}$ & $\begin{array}{l}-0.106 \\
(0.220)\end{array}$ \\
\hline Distance to the nearest CSU (miles) & $\begin{array}{c}0.011 \\
(0.018)\end{array}$ & $\begin{array}{l}-0.014 \\
(0.012)\end{array}$ & $\begin{array}{l}0.023 \\
(0.025)\end{array}$ & $\begin{array}{c}0.000 \\
(0.002)\end{array}$ & $\begin{array}{l}-0.018^{* *} \\
(0.009)\end{array}$ & $\begin{array}{l}0.006 \\
(0.010)\end{array}$ & $\begin{array}{l}0.007 \\
(0.008)\end{array}$ \\
\hline Student Population (1,000's) & $\begin{array}{c}0.158^{*} \\
(0.080)\end{array}$ & $\begin{array}{l}0.028 \\
(0.054)\end{array}$ & $\begin{array}{l}0.404^{* * *} \\
(0.113)\end{array}$ & $\begin{array}{l}0.024^{* *} \\
(0.011)\end{array}$ & $\begin{array}{l}0.082^{* *} \\
(0.040)\end{array}$ & $\begin{array}{l}0.066 \\
(0.045)\end{array}$ & $\begin{array}{l}0.053 \\
(0.034)\end{array}$ \\
\hline Fraction Vocational Education Degrees/Certificates & $\begin{array}{l}-0.089^{* * *} \\
(0.030)\end{array}$ & $\begin{array}{c}-0.023 \\
(0.020)\end{array}$ & $\begin{array}{c}-0.042 \\
(0.042)\end{array}$ & $\begin{array}{l}0.009^{* *} \\
(0.004)\end{array}$ & $\begin{array}{c}-0.006 \\
(0.015) \\
\end{array}$ & $\begin{array}{c}-0.003 \\
(0.017) \\
\end{array}$ & $\begin{array}{l}-0.018 \\
(0.013) \\
\end{array}$ \\
\hline \# of Community Colleges & 102 & 102 & 102 & 102 & 102 & 102 & 102 \\
\hline R-squared & 0.164 & 0.058 & 0.162 & 0.155 & 0.164 & 0.06 & 0.096 \\
\hline
\end{tabular}


Figure 1. Distribution of Outcomes by Community College
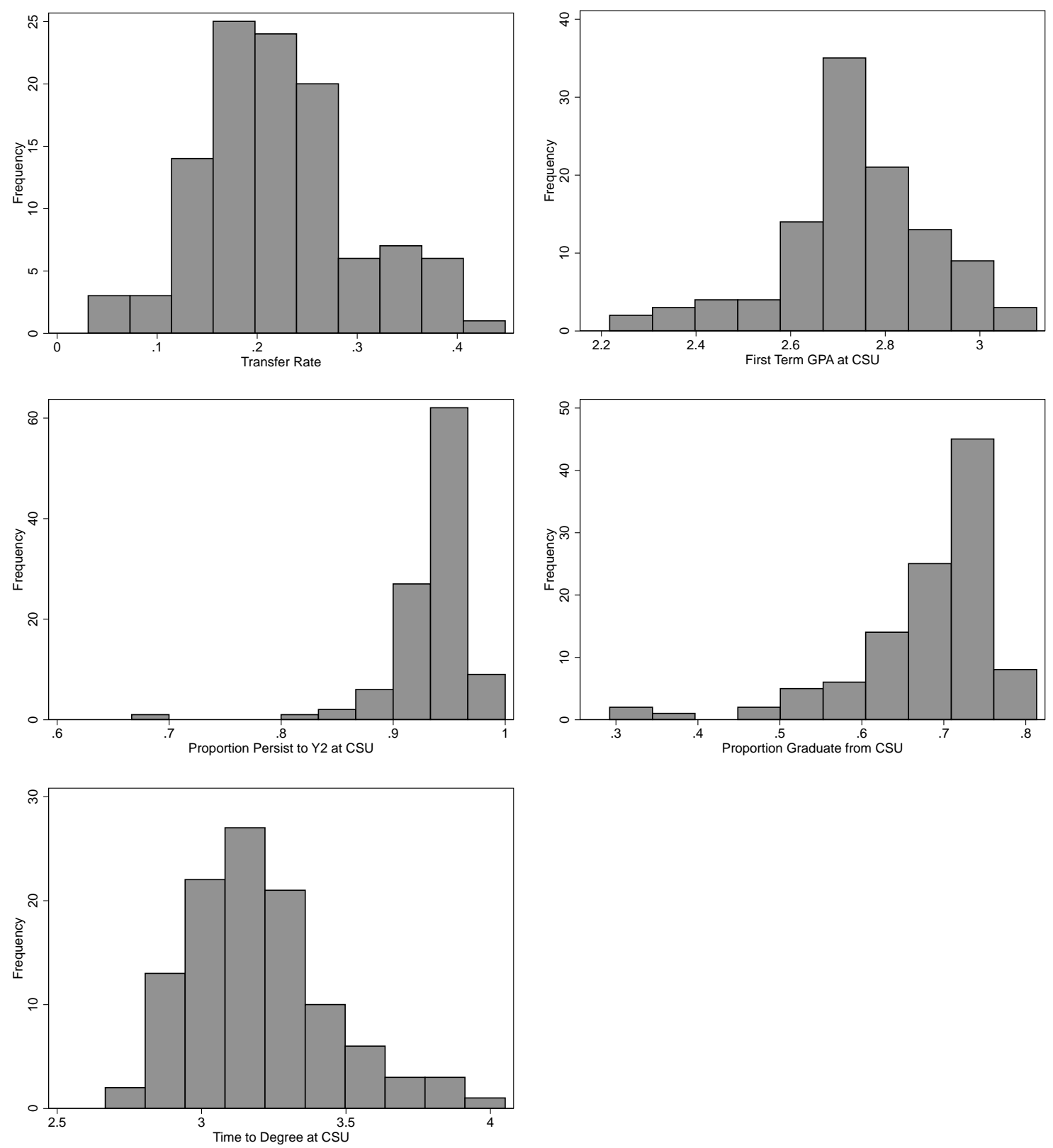

Source: Author's Calculations, based on data from CSU and CCCO Chancellor's Offices 
Figure 2. Distribution of Outcomes by Community College and CSU
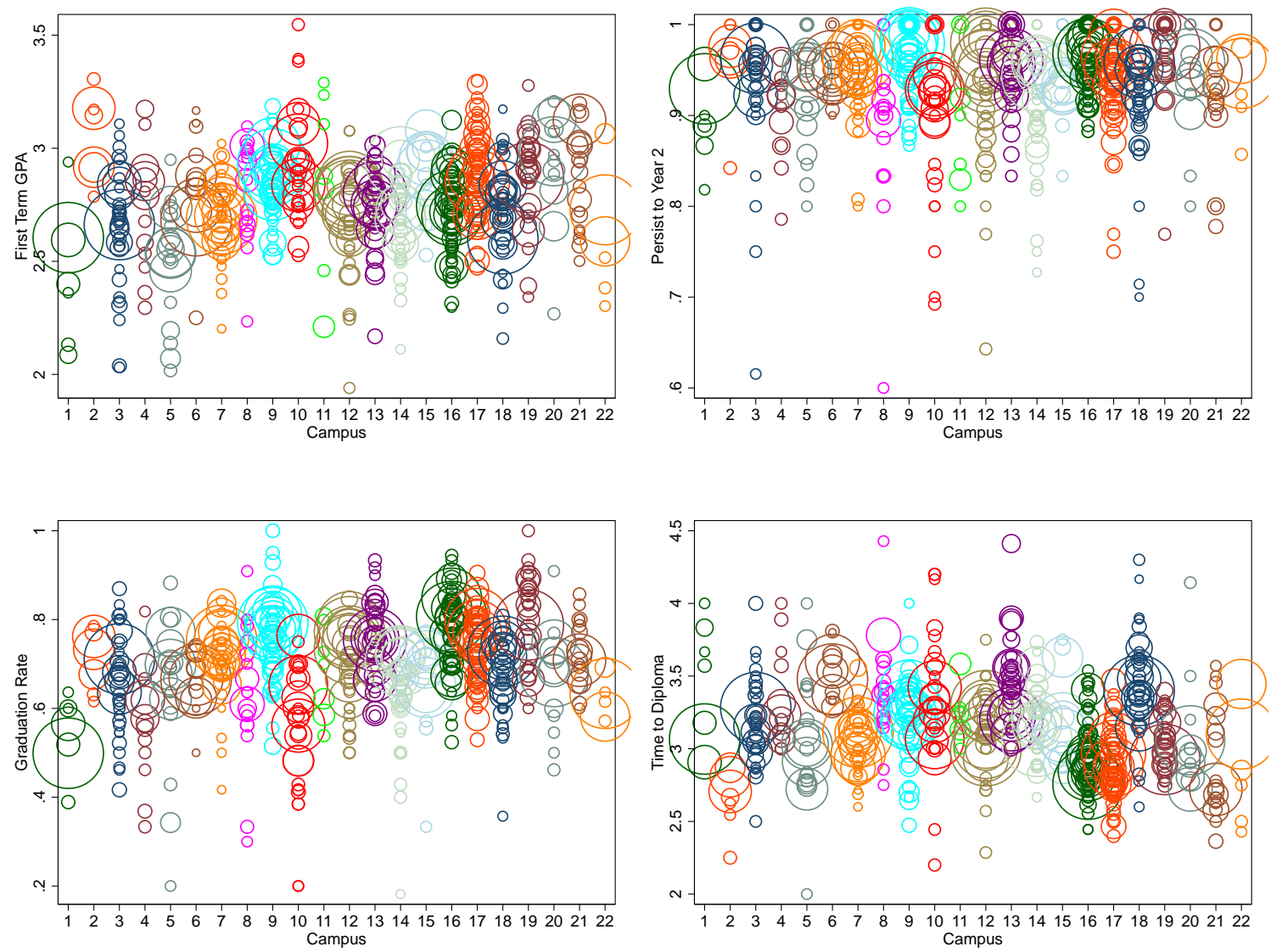

Source: Author's Calculations, based on data from CSU and CCCO Chancellor's Offices 
Figure 3. Scatterplot of Average CSU Outcomes against Students' $11^{\text {th }}$ Grade Math Test Scores
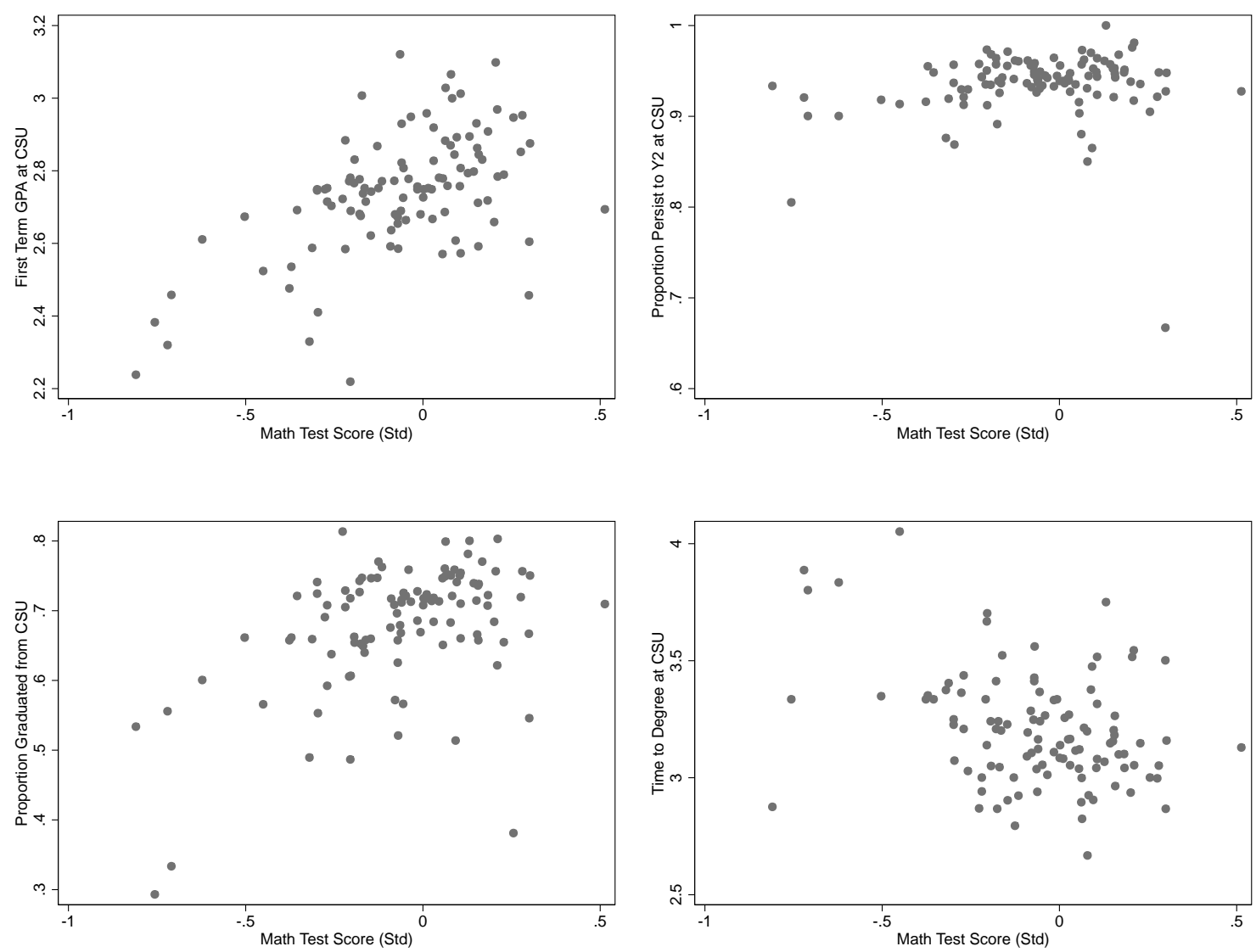

Source: Author's Calculations, based on data from CSU and CCCO Chancellor's Offices 
Figure 4. Ranked college effects for each community college, by outcome from fully specified model (Model 5, Table 4)
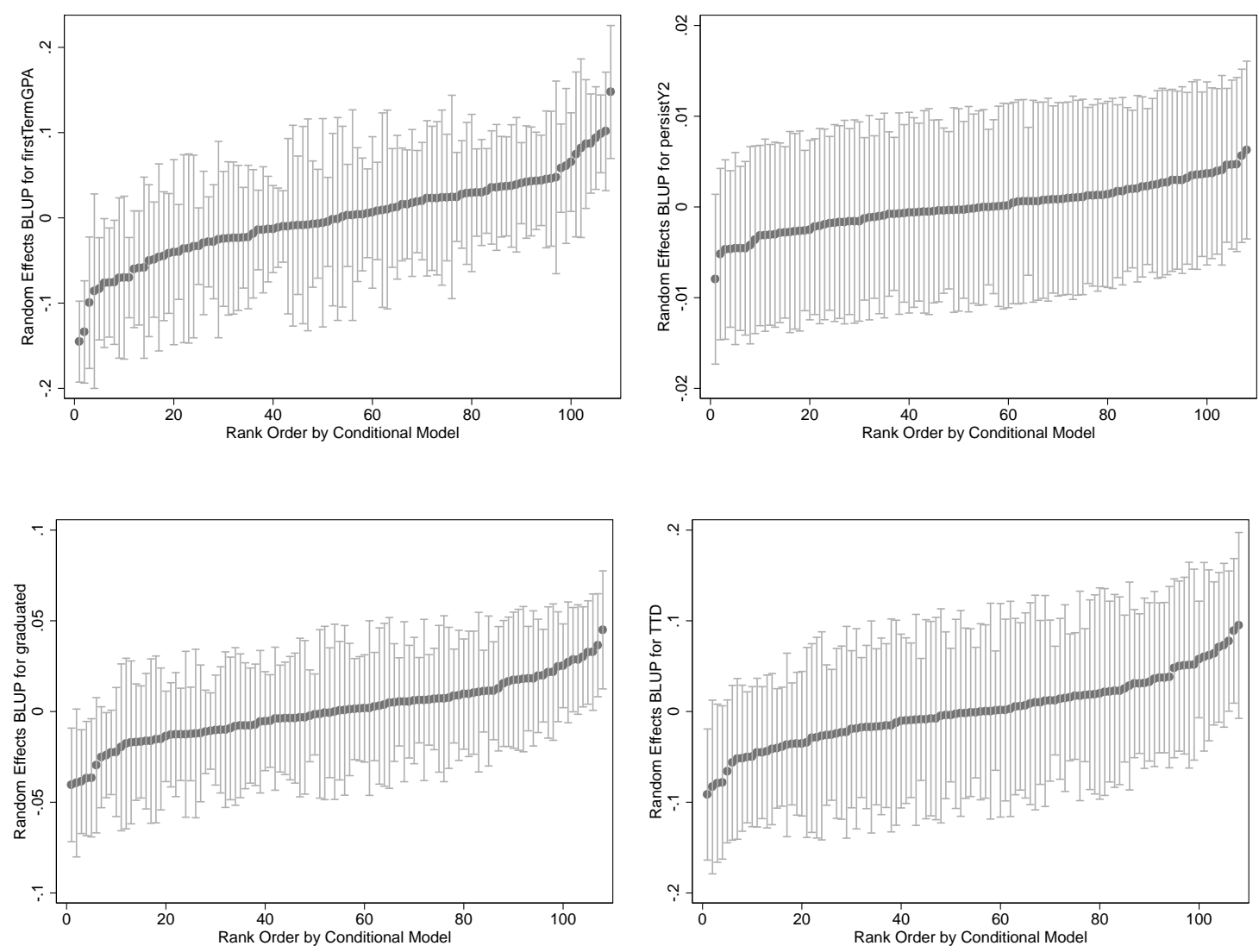

Source: Author's Calculations, based on data from CSU and CCCO Chancellor's Offices 
Figure 5. Intensive Transfer Margin versus Extensive Transfer Margin
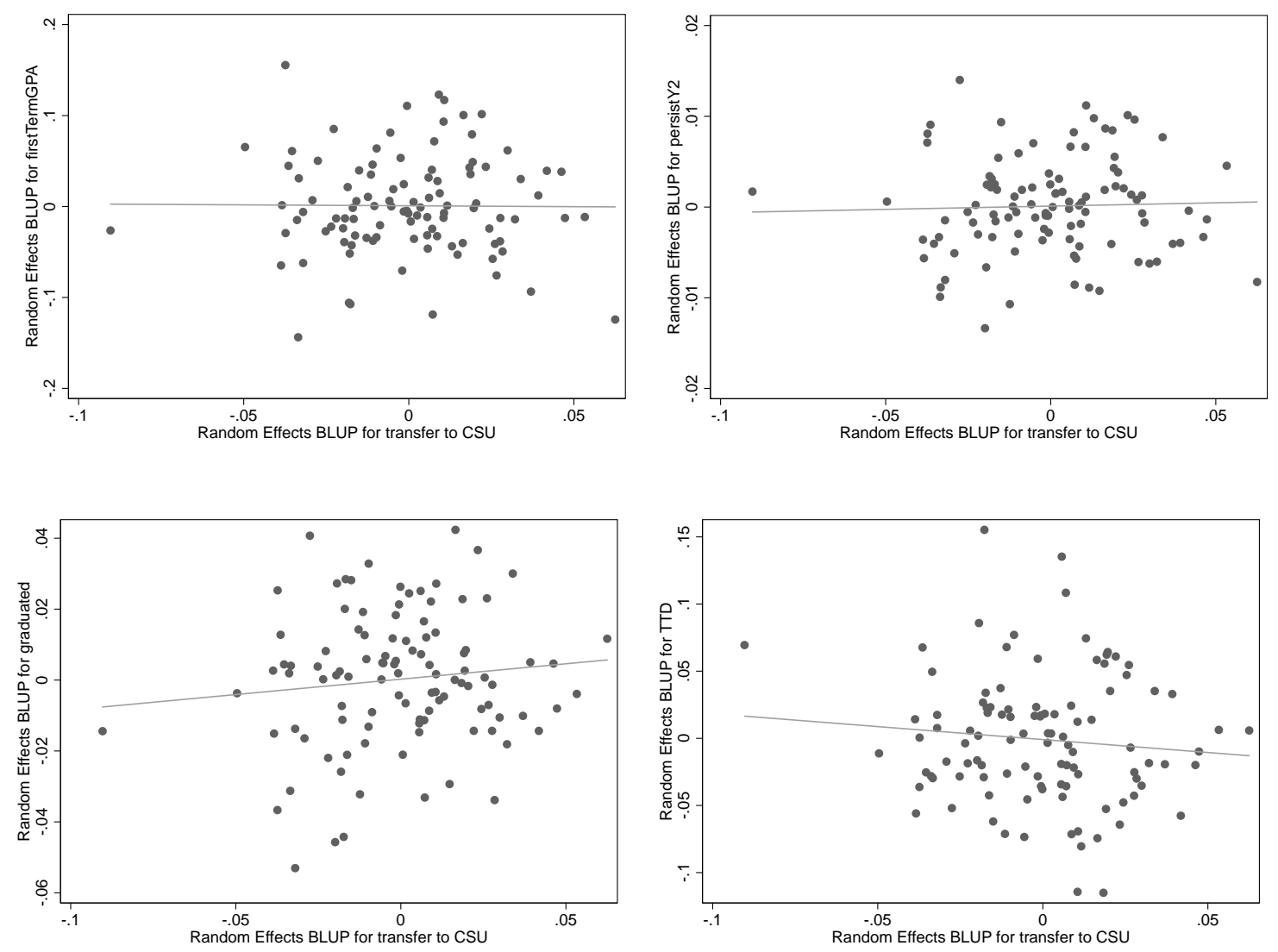

Source: Author's Calculations, based on data from CSU and CCCO Chancellor's Offices 